\title{
体内動態から見た薬物の親油性について
}

\section{Lipophilicity of Drugs from Pharmacokinetic Point of View}

\author{
広 橋 敏 之 \\ 住友製薬株式会社研究所 厂554 大阪市此花区春日出中3-1-98
}

\begin{abstract}
Summary
A Cell is a basic unit of the living body. It is separated from extracellular space by the cell membrane, which consists of lipid bilayers. When a drug is administered to the body, it contacts inevitably with the cell membranes. Therefore, its fate in the body must be strongly influenced by its liopphilicity which determines its degree of penetrability through the cell membranes.

For this reason, it is necessary for us to know the boundary between lipophilicity and hydrophilicity of drugs from the pharmacokinetic point of view. In order to clarify this boundary, I tried to analyze the relationship between partition coefficients and several pharmacokinetic parameters of various drugs and found some regularities, represented as below ;

1) Drugs $\left(\log \mathrm{P}^{*}>-2\right)$ are lipophilic from the viewpoint of volume of distribution.

2) Drugs $\left(\log \mathrm{P}^{*}<-1\right)$ are hydrophilic, whereas, drugs $\left(\log \mathrm{P}^{*}>0\right)$ are lipohilic

from the viewpoint of the rate of excretion unchanged in urine.
\end{abstract}

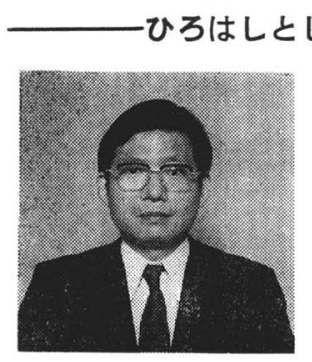

1963年, 東京大学薬学部卒. 住友化学に入社, 後, 住友製薬に移り, 現在に至っていま す.この間, ずっと研究生活です. 最初は合成をやっていましたが，ある時，一連の化合 物を合成しているらちに，ある現象を見つけ，坪井教授の御指導の下にま之め，『双環性 チオフェン誘導体の NMR による研究』で薬学博士号をいただきました。このように合 成をやりながらも日頃から物性に與味を持って括りましたところ，1975年，当時の上司で あった 故山本久夫博士の指示により, 薬物の物性と効力の関係についての研究を開始し ました. 全くの素人なもので, 何とか世の中の動きについて行ける方法はないものかと考 えた末，かねがね梅棹忠夫先生著の『知的生産の技術』（岩波新書）に感銘を受けていた こともあって, 関係のありそうな文献を手当たり次第にパンチカード化することを思いる きました、あれから11年，2万枚たまったカードから関係文献を選び出し書いたのがこの 論文です．これだけの自由度を与えていただいた会社には感謝の他ありません。 


\section{1. はじめに}

生体の最小単位は細胞であり, 細胞は細胞外と は脂質二重層からなる細胞膜で区切られている. したがって, 薬物を生体内に投与した場合, 薬物 は細胞膜と接触することになり，その生体内動態 は薬物の細胞膜透過能により大きな影響を受ける ことになる. この透過能は薬物の持つ親油性の程 度に左右される。なぜなら脂質膜を透過するに は，薬物はある程度の親油性を持つ必要があるか らである.さて, 親油性の指標としては, n一オク タノール/pH 7.4 バッファー水間の分配率 (log $\left.\mathrm{P}^{*}\right)$ がよく用いられている.この指標で表した場 合, 汇とんどの薬物はー4から4の間に位置する.

ところで，薬物を設計する立場から見て，知り

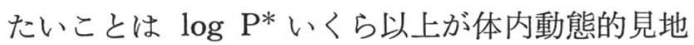
から親油性の薬物と言觉るかといらことである.

Rekker は薬物がオクタノール/水系の 分配率で $\log \mathrm{P}>0$ なら親油性, $\log \mathrm{P}<0$ なら親水性と考 えられると述べている12. しかしながら，この定 義は, オクタノール・水間の分配率で $\log \mathrm{P}>0$ が親油性と言うことで，オクタノールとは性質が 異なる生体膜と細胞外液間の分配に関してはこれ とは違った数字になると考兄られる。この点を知 るために著者は，これまでに報告されている各種 薬物の体内動態データ（ヒト, 静脈 内投与） と $\log \mathrm{P}^{*}$ との関係を整理, 解析する試みを行った ので，その結果について報告する.

\section{In vitro 細胞系より見た薬物の親油性}

\section{2-1 アミノ酸}

Willson らは, 各種アミノ酸のリポソームに対 する透過性について, 最も親油性の大きいPhenylalanineを 100 とした時の值を出しており

(Table I), 同時に, 八ト赤血球膜に括けるおの おののアミノ酸の能動輸送能についても調べてい る2)。これによると，アミノ酸のリポソーム膜透 過性は $\log \mathrm{P}^{*}$ 值がー 2 以上のアミノ酸ではかな り認められる一方, - 3 近くのものにはほとんど 認められない。これとは逆に, 能動輸送能は, -3 近くのアミノ酸に大きく認められ, -1.5 程度 のものにはほとんど認められず, これらのことか ら Willsonらは, アミノ酸の生体膜透過には脂質
Table I. Permeability of Phospholipid Vesicles to Amino Acids : Correlation between Permeability and Partition Coefficient

\begin{tabular}{lcc}
\hline \hline & $\log \mathrm{P}^{* a}$ & $\begin{array}{c}\text { Relative } \\
\text { Permeability }\end{array}$ \\
\hline Phenylalanine & -1.35 & 100 \\
Leucine & -1.51 & 84 \\
Isoleucine & -1.68 & 75 \\
Methionine & -1.87 & 38 \\
Alanine & -2.71 & 14 \\
Glycine & -3.00 & 2 \\
\hline
\end{tabular}

$\begin{array}{ll}\text { a) Ref. } 3 & \text { d) Ref. } 2\end{array}$

膜経由のものとキャリヤー蛋白経由のものの両方 が関与していると考㝋ている2).

\section{2-2 カテコールアミン誘導体}

カテコールアミン系の神経ホルモン関連物質 も, アミノ酸と同様, 分配率が低く, このため, 脂質膜経由では細胞を透過できず，代わりにキャ リヤー蛋白により細胞内に取り込まれることが知 られている.ところが, Mack と Bonisch は, カテュールアミン類のラット灌流心臓への取込み を調べた結果，これには，能動輸送だけでなく， 脂質膜経由による受動輸送も関係することを見出 しだ).この受動輸送は, 分配率の大きいものの ほうに顕著に認められたという。すなわち， log $\mathrm{P}^{*}$ 值の大きい amphetamin $(-0.79)$, isoprenaline (-1.66), phenylephrine $(-1.68)$ のほう が小さい noradrenaline (-2.79) より大で, 分 配率最大の amphetamine の場合には, 取込みは 脂質膜経由のほうがはるかに大で, このため能動 輸送による部分は, マスクされて表れてこないと 報告されている ${ }^{4)}$.

\section{2-3 ペニシリン系薬物}

ペニシリン系薬物も親水性大と普通, 考兄られ ているが, Kornguth と Kunin は赤血球へのこ れらの薬物の取込みを調べた結果, dicloxacillin は, penicillin G より取込み量が大であることを 見出し，この現象を脂溶性の差によると考㝋てお $\eta^{5)}$, 同様の現象を西田らも見い出している (Table II).

以上の文献データをまとめると, 物質の脂質膜 透過は, $\log \mathrm{P}^{*}$ 值でー 3 では認められずー2.5程 度から少し認められ, -1.5 以上あれば顕著に認め 
Table II. Uptake of Penicillins by Human Erythrocyte : Correlation between Uptake and Partition Coefficient

\begin{tabular}{lccc}
\hline \hline & & \multicolumn{2}{c}{ Uptake (\%) } \\
\cline { 3 - 4 } & $\log \mathrm{P}^{*}$ & Ref. 5 & Ref. 6 \\
\hline Dicloxacillin & $-0.60^{7)}$ & 22 & 35.3 \\
Propicillin & $-0.70^{7)}$ & & 19.4 \\
Penicillin G & $-1.69^{8)}$ & 5.5 & \\
Ampicillin & $-2.1^{9)}$ & & 4.1 \\
\hline
\end{tabular}

7) 9) each number corresponds to that of the reference.

られると考朰てよいのではないかと思われる，と ころで,水の分配率は一-1.38 と報告されている ${ }^{10)}$. 以上のことを考兄合わせると，物質の脂質膜透過 性は $\log \mathrm{P}^{*}$ 值のー1.5を境にして，それ以上あ れば親油性, 以下なら親水性と考兄てよいと思わ れる。すすおわ，水より蹯水性が大であれば親油 性で, 逆に水より疎水性が小であれば親水性物質 と考学るのである。この考方方にしたがえば，こ れまで，ペニシリン系薬物はすべて親水性と思わ れていたが，実は dicloxacillin などは親油性で あり, 一方, ampicillin などは従来通り親水性で あるということができる。

\section{3. 分布容量から見た薬物の親油性について}

人体を単純化して考觉ると図のごとく描ける (Fig 1).すすおわ，血漿, 細胞外液之細胞系に 分けることができ，血漿と細胞外液間は，毛細血 管で区切られている.ささて, 体重 $70 \mathrm{~kg}$ の人間に

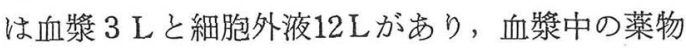
は，毛細血管の細孔を通って自由に細胞外液まで 分布できる、したがって，薬物の血漿中濃度と細 胞外液濃度は，大まかにいって注涪等しいと考克 てよい。

ところで, 細胞表面まで到達した薬物は, 膜を 通るのに十分な親油性を持っていれば，その内の 血漿蛋白非結合型の部分のみが，膜を通って細胞 内まで分布できる、したがって，極めて親水性の 大きな薬物を考えると，この薬物は細胞外液をで は分布できるが，膜を通るだけの親油性を有して いないために，分布は血漿中と細胞外液のみに限 られる。したがって, 分布容量は $15 \mathrm{~L}$,すなわち, $0.2 \mathrm{~L} / \mathrm{kg}$ となる.これが通常の薬物の場合の最

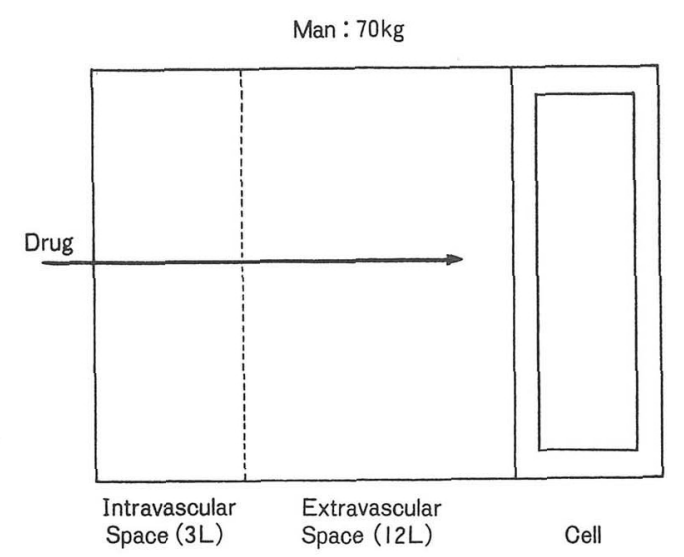

Fig. 1. Model for Drug Distribution

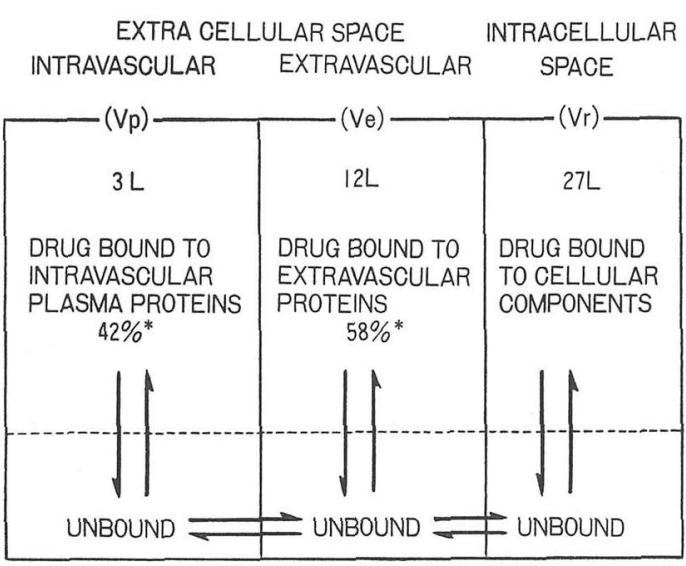

* albumin \%

Fig. 2. Model for Drug Distribution by Tozer ${ }^{11}$

小の分布容量で，したがって，いかに分配率が小 さくても分布容量は $0.2 \mathrm{~L} / \mathrm{kg}$ はあるわけであ る. 逆にい党ば, 膜を透過するに足る親油性を持 つ薬物の場合は, 分布容量は $0.2 \mathrm{~L} / \mathrm{kg} か ら$, そ の親油性に応じて大さくなることが予想できる。 このような視点から $\log \mathrm{P}^{*}$ いくら以上から, 膜 を通って細胞内にまで分布するよらになるのか解 析を試みた。

な拈, 実際の解析に当っては, 考方方は上に述 ベたことと同じであるが，血漿蛋白結合について より定量的に取り扱っている Tozer の方法によ った ${ }^{11)}$.この方法では, 人体を血管内容量 $(\mathrm{Vp})$, 細胞外液量 $(\mathrm{Ve})$ 括よび細胞内容量 $(\mathrm{Vr})$ とし, アルブミン存在比率を Vp 内に $42 \%$, Ve 内に 58 \%とし，薬物は各コンパートメント間を非結合型 のみで行き来し，抒の括ののコンパートメント内 
Table III. $\beta$-Lactam Antibiotics : Correlation between Intracellular Volume of Distribution and Partition Coefficient

\begin{tabular}{|c|c|c|c|c|c|c|}
\hline & & $\log \mathrm{P}^{b)}$ & $\log \mathrm{P}^{*}$ & $\mathrm{Vd}(l / \mathrm{kg})$ & $\mathrm{fu}^{\mathrm{c})}$ & $\mathrm{V}_{\mathrm{ic}} / 70(l / \mathrm{kg})$ \\
\hline 1 & Nafcillin & & $-0.50^{8)}$ & $0.63^{14) d)}$ & $0.10^{14)}$ & 5.1 \\
\hline 2 & Dicloxacillin & $2.91^{7)}$ & $-0.60^{7)}$ & $0.28^{14) d)}$ & $0.03^{14)}$ & 6.0 \\
\hline 3 & Cloxacillin & $2.43^{7)}$ & & $0.34^{(4) d)}$ & $0.05^{14)}$ & 4.7 \\
\hline 4 & Oxacillin & $2 \cdot 31^{7)}$ & $-1.15^{8)}$ & $0.41^{14) d)}$ & $0.07^{14)}$ & $4 \cdot 3$ \\
\hline 5 & Penicillin V & $1.95^{7)}$ & $-1.65^{7)}$ & $0.15^{(5) d)}$ & $0.20^{15)}$ & 1.9 \\
\hline 6 & Penicillin G & $1.70^{7)}$ & $-1.69^{8)}$ & $0.31^{14) d)}$ & $0.37^{14)}$ & 0.5 \\
\hline 7 & Meticillin & $1.30^{7)}$ & $-2.0^{8)}$ & $0.31^{16)}$ & $0.60^{16)}$ & 0.2 \\
\hline 8 & Ampicillin & & $-2.1^{9)}$ & $0.28^{14) d)}$ & $0.75^{14)}$ & 0.1 \\
\hline 9 & Cephalothin & $0.95^{7)}$ & $-3^{(a)}$ & $0.27^{14) d)}$ & $0.35^{14)}$ & 0.4 \\
\hline & Cefamandol & $0.50^{12)}$ & $-3.5^{a)}$ & $0.18^{17) d)}$ & $0.26^{17)}$ & 0.2 \\
\hline 11 & Cefoxitin & $-0.02^{12)}$ & $-4^{a)}$ & $0,14^{17)}$ & $0.27^{19)}$ & 0 \\
\hline 12 & Cefuroxime & $-0.16^{12)}$ & $-4 \cdot 2^{a)}$ & $0.19^{17)}$ & $0.67^{17)}$ & 0 \\
\hline & Cefazolin & $-0.24^{12)}$ & $-4.2^{a)}$ & $0.13^{17) d)}$ & $0.15^{17)}$ & 0 \\
\hline 14 & Cephacetrile & $-0.45^{12)}$ & $-4.5^{a)}$ & $0.30^{19)}$ & $0.60^{17)}$ & 0.1 \\
\hline 15 & Cefotaxime & $-1.05^{12)}$ & $-5.1^{a)}$ & $\left.0.31^{18) d}\right)$ & $0.60^{17)}$ & 0.2 \\
\hline
\end{tabular}

a) $\log \mathrm{P}^{*}$; calculated from $\log \mathrm{P}^{*}=\log \mathrm{P}-4$ (Ref. 13)

b) partition coefficient (unionized form)

c) fraction unbound to plasma proteins

d) assuming body weight as $70 \mathrm{~kg}$

7 ) 18) each number corresponds to that of the reference.

ではそれぞれ，アルブミンまたは細胞内組成物と 可逆結合すると考劣るのである (Fig. 2). この考 え方によれば，全体としての分布容量 (V) は式 (1) で表されることになる ${ }^{11}$.

$\mathrm{V}=\mathrm{Vp}+\mathrm{fu} \cdot \mathrm{Ve}+\mathrm{Vp} \cdot \mathrm{Re} / \mathrm{i}(1-\mathrm{fu})+\mathrm{fu} \cdot \mathrm{Vic}$

ここで, V, apparent volume of distribution; $\mathrm{Re} / \mathrm{i}$, alubumin content ratio (extravascular/ intravascular) ; fu, fraction in plasma unbound; Vic, intracellular volume of distribution ;

ただし，式(1)で Vic としたが，原式では Vr/ fur (ただし, Vr: volume of cellular space. fur: fract. unbound in space Vr) となってお り,ここではこれを細胞内分布容量と考えたもの である。

ところで，体重を $70 \mathrm{~kg}$ とすれば, $\mathrm{Re} / \mathrm{i}=1.4$, $\mathrm{Vp}=3 \mathrm{~L}, \mathrm{Ve}=12 \mathrm{~L}$ ゆ光, 式(1)を変形して, 体 重 $1 \mathrm{~kg}$ 当たりの細胞内分布容量を得ることがで きる。

$\mathrm{Vic} / 70(\mathrm{~L} / \mathrm{kg})=(\mathrm{V}-7.2-7.8 \cdot \mathrm{fu}) / 70 \cdot \mathrm{fu} \quad$ (2) さて，この式(2)を用いて解析するための薬物群 としては $\log \mathrm{P}^{*}$ 值でー 4 からー0.5におよぶ分 配率の小さい所に連続的に薬物が存在する $\beta$-ラ

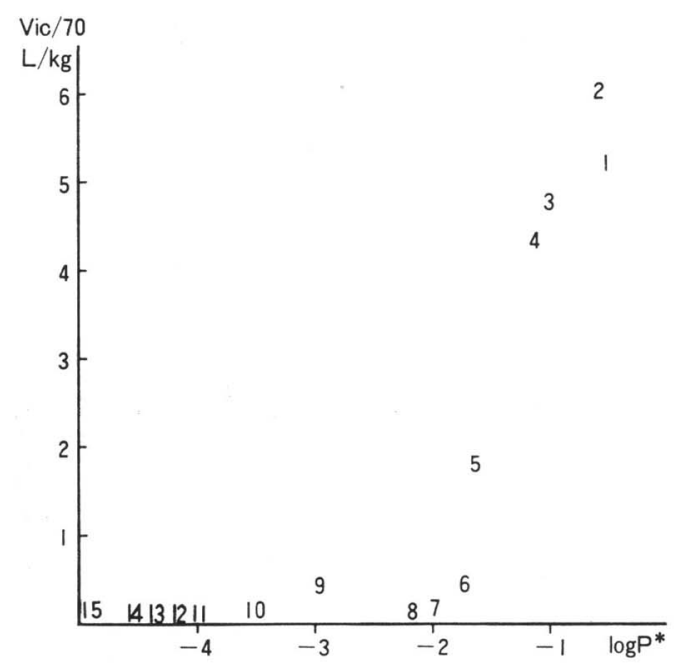

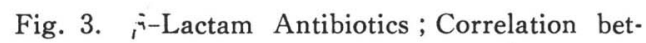
ween Intracellular Volume of Distribution and Partition Coefficient. (Each figure corresponds to that of Table III.)

クタム系抗菌剤が適当であると考学られた。そこ で, 各種 $\beta$-ラクタム系抗菌剂の内, $\log \mathrm{P}^{*}$ と人 での分布容量, および血漿蛋白結合率のわかって いるものを選びだし，細胞内分布容量を計算した 
Table IV. Intracellular Volume of distribution of $\beta$-Adrenoceptor Blocking Agents : Correlation between Intracellular Volume of Distribution and Partition Coefficient

\begin{tabular}{lcccc}
\hline \hline & $\log \mathrm{P}^{* a)}$ & $\mathrm{Vd}(l / \mathrm{kg})^{a)}$ & $\left.\mathrm{f}_{\mathrm{u}} a\right)$ & $\mathrm{V}_{\mathrm{ic}} / 70(l / \mathrm{kg})$ \\
\hline Bufuralol & 1.79 & 1.9 & 0.09 & 20.0 \\
Tolamolol & 1.51 & 2.1 & 0.09 & 22.0 \\
Propranolol & 1.13 & 2.0 & 0.07 & 27.0 \\
Alprenolol & 0.97 & 1.07 & 0,24 & 3.9 \\
Oxyprenolol & 0.20 & $1.2^{b)}$ & 0.08 & 13.6 \\
Acebutolol & -0.20 & 1.32 & 0.74 & 1.5 \\
Timolol & -0.22 & $1.6^{b)}$ & 0.40 & 3.6 \\
Metoprolol & -0.30 & 3.2 & 0.92 & 3.3 \\
Pindolol & -0.38 & 1.2 & 0.41 & 2.5 \\
Practolol & -1.30 & $1.6^{b)}$ & 0,93 & 1.5 \\
Atenolol & -1.69 & 1.1 & 0.97 & 0.9 \\
Nadolol & -1.69 & 1.9 & 0.72 & 2.4 \\
Sotalol & -2.00 & 1.35 & 1.00 & 1.1 \\
\hline
\end{tabular}

a) Ref. 20 ; assuming body weight : $70 \mathrm{~kg}$

b) Ref. 21

(Table III). この值と, $\log \mathrm{P}^{*}$ 值の関係を示し たのが Fig. 3 である。図から, 明らかに $\log \mathrm{P}^{*}$ 值でー 2 以下の薬物は細胞内に移行できないのに 対し, -2 以上のものは分配率が大きくなるにし たがって細胞内移行が増加することがわかる.こ のことは, 本系列の薬物では $\log \mathrm{P}^{*}$ 值でー 2 以 上になると細胞膜を透過できるようになることを 示していると考えられる.

ここで視点を変えてペニシリン系薬物の経口吸 収性について見ると, 脂質膜経由で吸収されると いう薬剤はすべて $\log \mathrm{P}^{*}$ 值でー1.69の Penicillin $\mathrm{G}$ 以上の分配率を有するものであることがわか る.これに対しー 2 以下の Meticillin や Carbenicillin には注射剤しかない。この事実も, $\log \mathrm{P}^{*}$ 值でー 2 が細胞膜透過のボーダーラインであるこ とを示している.すなわち, 薬物の経口吸収性と 細胞内移行性は, 一見全く異なる現象のようでは あるが, 膜透過性という点では, 同じ現象を見て いることになるわけである。

それでは， $\beta$-ラクタム系薬物群以外についても $\log \mathrm{P}^{*}$ 值 -2 が細胞内移行のボーダーラインで あるといらことが当てはまるのであろらか，今度 は，塩基性薬物について見ることにしょう，Hinderling らは, 一連の $\beta$-ブロッカー系薬物の $\log$ $\mathrm{P}^{*}$ 值と非結合型換算分布容量 $(\mathrm{Vd} / \mathrm{fu})$ との間に
相関があることを認めている ${ }^{201}$.とこで，これら の值を使って式(2)より細胞内分布容量（Vic）を 計算した（Table IV). 明らかに $\beta$-ブロッカー の場合も $\log \mathrm{P}^{*}$ 值 -2 から出発して分配率が大 になるほど細胞内分布容量も大きくなることがわ かる，ところで， $\beta$-ブロッカー系薬物には $\log \mathrm{P}^{*}$ 值一 2 以下のものはない. したがって， $\beta$-ラクタ ム系薬物で見られたような細胞膜透過性に関する 境界がー2であるかどらかについてはわからな い、しかしながら, 同じ塩基性薬物であるアミ， グリコシド系抗菌剂である Neomycin の $\log \mathrm{P}^{*}$ 值はー 2 以下であり ${ }^{8)}$, その分布容量は $0.3 l / \mathrm{kg}^{22)}$ とほぼ細胞外液どまりであることから, 塩基性薬 物の場合にも, $\log \mathrm{P}^{*}$ 值で -2 前後のところに 境界があるのではないかと考兄られる。

\section{4. 尿中未変化体排泄率から見た薬物の親油性 について}

血漿中に入った薬物は, 腎藏で濾過され, また あるものはさらに尿細管分泌により尿中に出る が，親油性の大きいものは一旦尿中に出ても遠位 尿細管から脂質膜経由で再吸収されて再び血液中 に戻る。したがって，このような場合は，肝蔵で 代謝を受けて, 親水性の代謝体にならないと尿中 に排泄されない，以上の関係を図括よび式で示す 


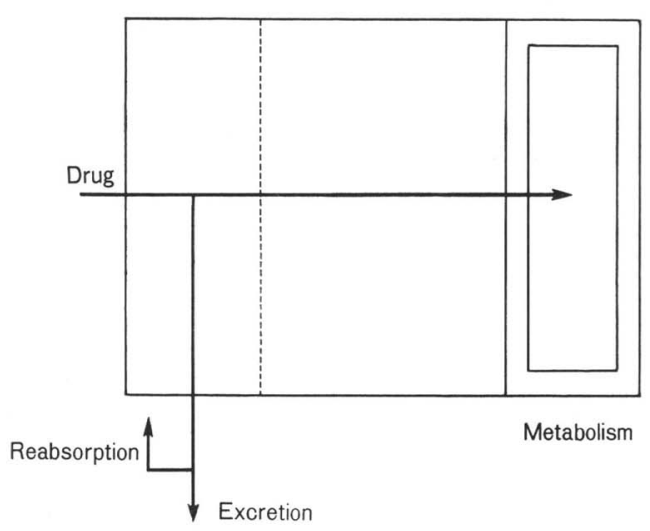

Fig. 4. Model for Drug Metabolism and Excretion.

(Fig. 4).

$\mathrm{Cl}_{\text {Serum }}=\mathrm{Cl}_{\text {Metab. }}+\mathrm{Cl}_{\text {Renal }}$

$\mathrm{Cl}_{\text {Renal }}=\mathrm{Cl}_{\text {Glom. }}+\mathrm{Cl}_{\text {Tub. }}$ - 再吸収

ここで, $\mathrm{Cl}_{\text {Serum, }}$ serum clearance; $\mathrm{Cl}_{\text {Metab., }}$ metabolic clarance ;

$\mathrm{Cl}_{\text {Rena1, }}$ renal clearance; $\mathrm{Cl}_{\text {Glom }}$., clearance by glomerular filtration ;

$\mathrm{Cl}_{\text {Tub., }}$, clearance by tubular secretion.

さて，この関係にに生体が薬物を親油性かどう かについて認識する籄所が二つある。一つは肝代 謝であり，もら一つは尿細管での再吸収において である。ただし，肝代謝では，たと党親油性が大 であったとしても，薬物によっては構造的に代謝 されないものもあるが，ここで知りたいことは， 分配率いくら以下なら代謝をらけないかといらこ とである。

\section{4-1 肝ミクロソーム P-450 による代謝から見 た薬物の親油性}

薬物代謝は主として肝ミクロソームP-450によ り行われる. Gaudette と Brodie は, 分配率の 異なる各種 N-アルキルアミンを肝ミクロソーム 酵素で酸化的脱アルキル化を行わせたところ, あ る分配率以下のものは代謝を受けないことから， 肝細胞内で脂質膜 (ミクロソーム膜) が高度に非 選択的な反応を起こすミクロソーム酵素を包んで おり,このため, 親水性の大きい化合物は酸化さ れないと考えた ${ }^{23)}$.

さて, 放射線感度増強剤である Misonidazole 誘導体につき, マウスに静注して得られた尿中排 泄物を分析した Workman と Brown の報告に
よると，代謝は Misonidazole ( $\left.\log \mathrm{P}^{*}-0.37\right)$ 以上の分配率を有するものでは盛んに行われ，一 方, -1.33 以下の化合物では全く行われず, -0.92 の Desmethylmisonidazole では $5 \%$ 程度が代謝 されたと報告している24).

一方, ペニシリン系薬物の肝代謝に関しては, Robinson と Batchelor の報告がある ${ }^{25)}$. 彼らは 各種ペニシリン系薬物を人に投与し，先の尿中代 謝体の有無をペーパークロマトグラフィーを用 い，検出を抗菌活性で行っている. したがって， ここにいう代謝体にはラクタム環が加水分解され て抗菌活性を失ったものは含まれておらず，肝ミ クロソーム P-450による代謝の有無を示している ものと考宇られる. 結果は, Ampicillin, Methicillin では代謝体は認められず， Penicillin G, Penicillin V で 5\%程度, Phenethicillin で20\% 程度, Propicillin, Oxacillin, Cloxacillin では25 -30\%程度代謝されることがわかった ${ }^{25)}$ 。これを $\log \mathrm{P}^{*}$ 值で整理すると, -2 以下では全く代謝 されず, -1.5 付近から少しされ始め, -1 から -0.5では $30 \%$ 程度代謝されることになる.

以上をまとめて見ると, $\log \mathrm{P}^{*}$ 值でー 1 が代 謝が有意に行われる境界であるといえよう。

\section{4-2尿細管再吸収から見た 薬物の 親油性につ いて}

Toon と Rowland は一連のテトラサイクリン 系薬物につき $\log \mathrm{P}^{*}$ 值と腎クリアランス值 $\left(\mathrm{Cl}_{\mathrm{R}}\right)$ および分布容量との関係につき報告している26). 彼らの出した $\log \mathrm{P}^{*}$ 值, 血漿蛋白非結合型比率 (fu), 分布容量および非結合体換算腎クリアラ ンス值 $\left(\mathrm{Cl}_{\mathrm{R}} / \mathrm{fu}\right)$ を Table $\mathrm{V}$ に示した。 また, 参考までに，これらの值を使って式(2)より計算し て得た細胞内分布容量 (Vic) も示した. 薬物の $\log \mathrm{P}^{*}$ 值は-1.60の Oxytetracycline から0.04 の Minocycline までの分布があり, Toon らは解 析の結果, 非結合体換算腎クリアランス值はほぼ 糸球体濾過量に一致するため, これらの薬物は再 吸収されないと述べている ${ }^{26)}$. 確かに $\log \mathrm{P}^{*}$ 值 -0.22 の Doxycycline より分配率の小さいもの ではその通りであるが，詳細に見ると，0.04の Minocycline の場合には, 他の物とは異なり再吸 収が50\%程度あることを示唆するデータとなって いる、したがって，この系の薬物では $\log \mathrm{P}^{*}$ 值 
Table V. Renal Clearance of Tetracyclines: Correlation between Renal Clearance and Partition Coefficient

\begin{tabular}{lccccc}
\hline \hline & $\log \mathrm{P}^{* a)}$ & $\mathrm{fu}_{\mathrm{u}}\left({ }^{a)}\right.$ & $\mathrm{Vd}(1)^{a)}$ & $\mathrm{Cl}_{\mathrm{R}} / \mathrm{f}_{\mathrm{u}} a^{a}$ & $\mathrm{~V}_{\mathrm{ic}} / 70(l / \mathrm{kg})$ \\
\hline Oxytetracycline & -1.60 & 0.690 & 112.31 & 143 & 2.1 \\
Tetracycline & -1.44 & 0.405 & 95.45 & 181 & 3.0 \\
Demethylchlortetracycline & -1.30 & 0.250 & 118.99 & 141 & 6.1 \\
Chlortetracycline & -0.88 & 0.300 & 86.62 & 107 & 3.7 \\
Methacycline & -0.37 & 0.220 & 146.76 & 207 & 9.1 \\
Doxycycline & -0.22 & 0.125 & 79.37 & 147 & 8.1 \\
Minocycline & 0.04 & 0.240 & 188.86 & 63 & 10.5 \\
\hline
\end{tabular}

a) Ref. 26

-0.2 以下は再吸收されないことを示しており, 遠位尿細管の脂質膜は -0.2 以下のテトラサイク リンを親水性と判断したことになる。これに対し て, 細胞内分布容量は, 同じ薬物群で $\log \mathrm{P}^{*}$ 值 が大になるにしたがって大きくなることから，一 連の薬物をすべて親油性と認めていることを示し ている、このように, 同じ生体膜とはい光組織毎 に少しずつ組成が異なり，このため，薬物に対す る親水性, 親油性の判断は組織毎に微妙に異なる ように思われる.あるいは, 尿細管再吸収の場合, 薬物は短い尿細管を水溶液として一方通行的に移 動しながら再吸収されねばならぬため, 膜吸収の 効率が他の場合と異なり悪くなり，かなり大きい 親油性を持つ薬物迄, 再吸収され切れずに排泄さ れるということかも知れない。

\section{4-3 $\beta$-ブロッカー系薬剤及び 各種抗不整脈剤 の分配率と尿中未変化体排泄率}

Hinderling らは $\beta$-ブロッカー系薬剤につき， Dryer は抗不整脈剤につき尿中未変化体排泄率を 出し，これと分配率との関係を報告している ${ }^{20,27)}$ (Fig. 5). 図から log $\mathrm{P}^{*}$ 值一 1 以下の薬物はほ ぼ全量が尿中に未変化体として排泄されるのにた いし，0以上の物は未変化体としてはほとんど排 泄されないことがわかる. この数字は, 肝ミク口 ソームP-450酵素による代謝と薬物の分配率との 関係とよく一致しているとい方よう.

では，この場合の代謝によるクリアランス值 $\left(\mathrm{Cl}_{\mathrm{M}}\right)$ と腎クリアランス值 $\left(\mathrm{Cl}_{\mathrm{R}}\right)$ に対する各薬 剤の分配率との関係はどうなっているのであるう か. Hinderling らは $\beta$-ブロッカー系薬剤につ き, $\log \mathrm{P}^{*}$ 值と腎および肝クリアランスの関係 を提出している（Table VI）。この表をもとにし

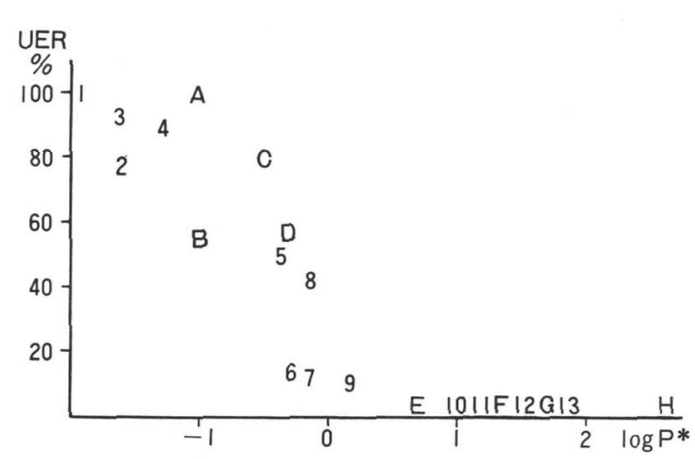

Fig. 5. $\beta$-Adrenoceptor Blocking Agents and Antiarrythmic Agents; Correlation between Urinary Excretion Rate and Partition Coefficient.

(Each figure represents an $\beta$-adrenoceptor blocking agent which correspond to the list in Table VI. Each alphabet represents an antiarrythmic agent; $\mathrm{A}$, bretylium. B, pro cainamide. $\mathrm{C}, \mathrm{N}$-acethylprocainamide. $\mathrm{D}$, disopyramide. E, mexiletine. F, aprindine. G, lidocaine. H, verapamil.)

て, $\beta$-ブロッカー系薬剤を $\log \mathrm{P}^{*}$ 值により以下 のごとく分類することができる.

A. 大部分が未変化体で尿中に排泄される型 $\log \mathrm{P}^{*}$ 值 -1.30 以下の薬物. 代謝はされ てもごく僅かである。

B. 尿中に数十\%が未変化で排泄される型 $\log \mathrm{P}^{*}$ 值一0.4から0までのもの.

この群の薬物では, 肝代謝が盛んに行われ る一方, 腎クリアランスも大である.すなわ ち, 肝代謝では親油性と認められるのに対し 尿細管再吸収過程では親水性々判断されてい ることを示している. このことはテトラサイ クリンの尿細管再吸収で $\log \mathrm{P}^{*}$ 值でー0.2 以下のものは再吸収されないと述べたことと 
Table VI. Urinary Excretion of $\beta$-Adrenoceptor Blocking Agents ${ }^{a}$ )

\begin{tabular}{|c|c|c|c|c|c|}
\hline & & \multirow{2}{*}{$\log \mathrm{P}^{*}$} & \multicolumn{2}{|c|}{$\begin{array}{l}\text { Clearance } \\
(\mathrm{m} l / \mathrm{min})\end{array}$} & \multirow{2}{*}{$\begin{array}{l}\text { Urinary } \\
\text { Excretion } \\
(\%)\end{array}$} \\
\hline & & & $\mathrm{Cl}_{\mathbf{M}}$ & $\mathrm{Cl}_{\mathrm{R}}$ & \\
\hline 1 & Sotalol & -2.00 & 0 & 159 & 100 \\
\hline 2 & Nadolol & -1.69 & 49 & 153 & 76 \\
\hline 3 & Atenolol & -1.69 & 10 & 168 & 94 \\
\hline 4 & Practolol & -1.30 & & & $90^{b)}$ \\
\hline 5 & Pindolol & -0.38 & 266 & 272 & 50 \\
\hline 6 & Metoprolol & -0.30 & 701 & 93 & 15 \\
\hline 7 & Timolol & -0.22 & 524 & 70 & 12 \\
\hline 8 & Acebutolol & -0.20 & 475 & 295 & 41 \\
\hline 9 & Oxprenolol & 0.20 & 174 & 22 & 11 \\
\hline 10 & Alprenolol & 0.97 & 435 & 18 & 2 \\
\hline 11 & Propranolol & 1.13 & 676 & 27 & 4 \\
\hline 12 & Tolamolol & 1.51 & 718 & 37 & 5 \\
\hline 13 & Bufuralol & 1.79 & 535 & 4 & 2 \\
\hline
\end{tabular}

$\begin{array}{lll}\text { a) Ref. } 20 & \text { b) Ref. } 28\end{array}$

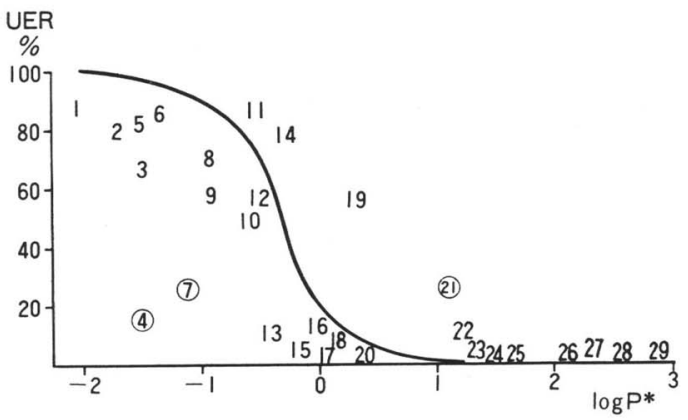

Fig. 6. Correlation between Urinary Excretion Rate and Partition Coeficient of Various Drugs.

(Each figure represents a drug which correspond to that of Table VII.)

一致している.

C. 尿中排泄率が $5 \%$ 以下のもの

$\log \mathrm{P}^{*}$ 值 1 以上のもの

この群の薬物では, 肝クリアランス值はほ ぼ肝血流量に等しく，盛んに代謝されること を示し，一方，腎クリアランス值からは再吸 収が効率よく行われることを示している。

以上をまとめると, この系の薬物では, 代謝は $\log \mathrm{P}^{*}$ 值一 1.3 以下のものでは行われない。一方 -0.4 以上では盛んに行われる。 これに対し, 尿 細管再吸収は 0 以下では汪とんど行われず， 1 以
Table VII. Urinary Excretion of various Drugs

\begin{tabular}{|c|c|c|c|}
\hline & M.W. & $\log \mathrm{P}^{*}$ & $\begin{array}{l}\text { Urinary } \\
\text { Excretion } \\
\quad(\%)\end{array}$ \\
\hline 1 Ampicillin & 347 & $-2 \cdot 10^{9)}$ & $83^{44)}$ \\
\hline 2 Ciprofloxacin & 331 & $-1.69^{29)}$ & $80^{45)}$ \\
\hline 3 Cinoxacin & 262 & $-1.52^{29)}$ & $65^{46)}$ \\
\hline 4 Phenylephrine & 168 & $-1.52^{30)}$ & $16^{47)}$ \\
\hline 5 Pipemidic acid & 303 & $-1.52^{29)}$ & $81^{48)}$ \\
\hline 6 Metformin & 129 & $-1.43^{31)}$ & $86^{49)}$ \\
\hline 7 Isoniazide $^{a)}$ & 137 & $-1.14^{10)}$ & $25^{16)}$ \\
\hline 8 Sulpiride & 341 & $-0.95^{32)}$ & $70^{50)}$ \\
\hline $\begin{array}{l}9 \text { Desmethyl- } \\
\text { misonidazole }\end{array}$ & 187 & $-0.92^{33)}$ & $59^{51)}$ \\
\hline 10 Pirenzepine & 351 & $-0.63^{35)}$ & $50^{52)}$ \\
\hline 11 Amantadine $\mathrm{e}^{a)}$ & 151 & $-0.55^{36)}$ & $86^{53)}$ \\
\hline 12 Atropine & 289 & $-0.44^{37)}$ & $58^{54)}$ \\
\hline 13 Misonidazole & 201 & $-0.37^{33)}$ & $10^{55)}$ \\
\hline 14 Acetazolamide $^{a}$ ) & 222 & $-0.25^{38)}$ & $80^{56)}$ \\
\hline 15 Morphine & 285 & $-0.12^{10)}$ & $9^{57)}$ \\
\hline 16 Piroxicam $^{a}$ & 335 & $-0.09^{39)}$ & $10^{58)}$ \\
\hline 17 Theophyllin ${ }^{a)}$ & 180 & $-0.02^{10)}$ & $8^{16)}$ \\
\hline 18 Pefloxacin & 333 & $0.12^{29)}$ & $9^{59)}$ \\
\hline 19 Cimetidine & 252 & $0.29^{b)}$ & $58^{60)}$ \\
\hline 20 Warfarin & 308 & $0.47^{41)}$ & $0^{16)}$ \\
\hline 21 Phenobarbital & 232 & $1.13^{37)}$ & $27^{61)}$ \\
\hline 22 Chloramphenicol & 323 & $1 \cdot 24^{42)}$ & $10>16)$ \\
\hline 23 Butobarbital ${ }^{a}$ ) & 234 & $1.26^{10)}$ & $8^{16)}$ \\
\hline 24 Amobarbital $^{a}$ & 226 & $1.58^{10)}$ & $0^{16)}$ \\
\hline 25 Desipramine $^{a)}$ & 266 & $1.48^{10)}$ & $10^{16)}$ \\
\hline 26 Oxazepam ${ }^{a)}$ & 287 & $2.17^{10)}$ & $0.2^{62)}$ \\
\hline 27 Fentanyl & 336 & $2 \cdot 35^{10)}$ & $6.5^{63)}$ \\
\hline 28 Bencylane & 289 & $2.60^{43)}$ & $3>64)$ \\
\hline 29 Diazepam & 285 & $2.82^{10)}$ & $0^{16)}$ \\
\hline
\end{tabular}

a) administraion route : P.O. (absorotion rate $>90 \%$

b ) $\log \mathrm{P}^{*}$ is calculated from $\log \mathrm{P}(0.39)$ and $\mathrm{pka}_{\mathrm{a}}(6.80)^{40)}$ by the method of Sherrer \& How ard ${ }^{34)}$

9) 64) each number corresponds to that of the reference

上では盛んに行われるといえる。

\section{4-4 各種薬物の分配率と尿中未変化体排泄率}

以上述べてきた薬物の分配率と尿中未変化体排 泄率の関係についての知見が，薬物一般に当ては まるのか否かを知るために， $\log \mathrm{P}^{*}$ 值およびヒ 卜静脈内投与による尿中未変化体排泄率がわかっ ている各種薬物をまとめた (Table VII, Fig. 6). な拈，分量 350 以下のものを選んだが，これは分 
子量が大きいと未変化体のまま胆汁排泄される可 能性があり, データの解析が困難になるからであ る。Fig. 6 には参考までに Fig. 5 で得られた尿 中未変化体排泄率と $\log \mathrm{P}^{*}$ との関係をわかり易 い上うに大体の線で示した. 図より各種薬物にま で拡大しても, ほぼ $\log \mathrm{P}^{*}$ 值でー 1 以下の薬物 は大部分が未変化体として尿中に出, これに対 し, $\log \mathrm{P}^{*} 0$ 以上は未変化体として尿中にほと んど出ないという関係は成立することがわかる。 ただし，ここでは，この規則に当てはまらない例 外がいくつかあり，これらを図中で印をつけて示 した.これらの例外につき，それぞれどのよらな 理由によるのかについては以下に考察を加えた.

ここで, 尿中未変化体排泄率 (UER) は式(3)で 表すことができる.

$$
\mathrm{UER}=\mathrm{Cl}_{\text {Renal }} /\left(\mathrm{Cl}_{\text {Metab }} .+\mathrm{Cl}_{\text {Renal }}\right)
$$

No. 4. Phenylephrine ; 代謝は P-450 ではなく グルクロナイド抱合による ${ }^{47)}$. 抱合の場合 には $\log \mathrm{P}^{*}$ 值との関係は $\mathrm{P}-450$ の場合と は異なるようである。

No. 7. Isoniazide ; アセチル化抱合による ${ }^{16)}$.

No.10. Pirenzepine; 胆汁排泄率が $48 \%$ もあ る ${ }^{52)}$. 分子量が大のため.

No.18. Pefloxacin; 例外ではないが, この薬物 の場合, 健常人では $9 \%$ の尿中排泄率に対 して, 肝疾患患者には $26 \%$ に増えること が知られている59).すなわち，この場合， 腎クリアランス值が同じでも肝クリアラン ス值に差があるためである. 式(3)参照のこ と.

No.20. Warfarin；血漿蛋白結合率 $99 \%{ }^{56)}$.この
ため，糸球体濾過されず，したがって尿中 に排泄されない.

No.21. Phenobarbital ; 代謝され難い. $\mathrm{Cl}_{\text {Total }}$ $3.5 \mathrm{ml} / \mathrm{min}$. $\mathrm{Cl}_{\text {Renal }} 0.9 \mathrm{ml} / \mathrm{min}$. Vd 0.6 $l / \mathrm{kg}, \mathrm{T}_{1 / 2} 139 \mathrm{hrs}^{61)}$. 分配率が大にもかか わらず，尿中に未変化体として $27 \%$ も出る 理由は, 代謝が極めて遅いために腎クリア ランスの絶対值は小さいにもかかわらず, その全クリアランス值に占める割合が相対 的に大きくなるためである.

したがって，この型の薬物の半減期は必 然的に極めて長いものとなる.

No.28. Bencyclane; $\mathrm{Cl}_{\text {Total } 1} 742 \mathrm{ml} / \mathrm{min} . \mathrm{Cl}_{\text {Renal }}$ $7 \mathrm{ml} / \mathrm{min}^{64)}$. 例外ではないが, $\log \mathrm{P}^{*}$ 值 2.60 という親油性の大さいものでも腎クリ アランス值が $7 \mathrm{ml} / \mathrm{min}$. もあることを示 す例. したがって, この薬物は肝クリアラ ンス值大のため尿中未变化体排泄率は $1 \%$ 程度であるが，何かの理由で肝クリアラン スが 0 となると，尿中に $100 \%$ 未変化で出 ることになろう。

\section{5. まとめ}

1）分布容量から見れば， $\log \mathrm{P}^{*}$ 值でー 2 以 上の薬物は親油性といえる.

2）尿中未変化体排泄率から見れば， $\log \mathrm{P}^{*}$ 值でー 1 以下は親水性, 0 以上は親油性とい える。

今後, 体内動態まで考虑に入れた薬物設計を行 う上で, この一般則は有用であると思われる。

\section{文献}

1) Rekker R.F. : The hydrophobic fragmental constant, pp.99, Elsevier, Amsterdam, Nederlands (1977).

2) Willson P.D. and Wheeler K.P. ; Permeability of phospholipid vesicles to amino acids. Biochemcal Soc. Transact., $1: 369-372$ (1973).

3) Klein R.A., Moore M.J. and Smith M.W. ; Selective diffusion of neutral amino acids across lipid bilayers. Biophimica et Biophysica Acta, 233 : 420-433(1971).

4) Mack F. and Bonisch H. ; Dissociation constants and lipophilicity of catecolamines and related compounds. Naunyn-Schmiedeberg's Arch. Pharmacol., $310: 1-9$ (1979).

5) Kornguth M.L. and Kunin C.M. ; Uptake of antibiotics by human erythrocytes. J. Infectious Diseases, $133: 175-184$ (1976).

6）西田 実, 松原忠男, 上村利明, 村川武雄, 横田好子 ; Penicillin 類と血清蛋白との 結合性に関する研究第 2 報, Penicillin 類の血清蛋白と赤血球内への移行の相関につ 
いて. The Japanese $J$. of Antibiotics, $23: 217-222$ (1970).

7) Tsuji A., Kubo O., Miyamoto E. and Yamana T.; Physicochemical properties of $\beta$-lactam antibiotics: Oil-water distribution. J. Pharm. Sci., 66 : 1675-1679 (1977).

8) Nikaido H.; Outer membrane of Salmonella tyhimurium; Transmembrane diffusion of some hydrophobic substances. Biochimica et Biophysica Acta, 433 : 118-132 (1976).

9) Carney C.F. and Hurwitz A.R. ; pH Partition behavior of ampicilin. J. Pharm. Sci., 66 : 294-295 (1977).

10) Hansch C. and Leo A. ; Partition coefficients ; Substiuent constants for correlation analysis in chemistry and biology. John Willey \& Sons, New york, USA, pp.169330 (1979).

11) Tozer T.N. ; Concepts basic to pharmacokinetics. Pharmac. Ther., $12: 109-131$ (1981).

12) Yoshimura F. and Nikaido H. ; Diffusion of $\beta$-lactam antibiotics through the porin channels of Escherichia coli K-12. Antimicrobial Agents and Chemotherapy, $27: 84-92$ (1985).

13) Rekker R.F. and de Kort H.M. ; The hydrophobic fragmental constant; an extension to a 1000 data point set. Eur. J. Med. Chem., 14:479-488 (1979).

14) Barza M. and Weinstein L. ; Some determinants of the distribution of penicillins and cephalosporins in the body. Practical and theoretical considerations. Ann. N.Y. Acad. Sci., 235 : 613-620 (1981).

15) Overbosch D., Mattie H. and van Furth R.; Comparative pharmacodynamics and clinical pharmacokinetics of phenoxymethylpenicillin and pheneticillin. $B r$. J. Clin. Pharmac., $19: 657-668$ (1985).

16) Ritschel W.A. ; Handbook of basic pharmacokinetics, second edition, appendix, Hamilton Press, Inc., USA (1980).

17) O'Callaghan C.H.; Description and classification of the newer cephalosporins and their relationships with the established compounds. J. of Antimicrobial Chemotherapy., 5 : 635-671 (1979).

18) Nightingale C.H., French M.A. and Quintiliani R. ; Cephalosporin pharmacokinetics; Beta-lactam antibiotics (edited by S. Mitsuhashi, Japan Scientific Society Press, Tokyo). pp.259-295 (1981).

19) Avery G.S. ; Drug treatment, second edition, appendix, Adis Press, New York, USA (1976).

20) Hinderling P.H., Schmidlin O. and Seydel J.K.; Quantitative relationships between structure and pharmacokinetics of beta-adrenoceptor blocking agents in man. J. of Pharmacokinetics and Biopharmaceutics, 12 : 263-287 (1984).

21) Frisk-Holmberg M. ; $\beta$-Adrenoceptor blocking drugs : A comparative evaluation of their present clinical effectiveness and perspectives. Current Therapeutic Research, 26 : 1027-1045 (1979).

22) Black W.D., Holt J.D. and Gentry R.D. ; Pharmacokinetic study of neomycin in calves following intravenous and intramuscular administration, Canadian J. Comp. Med. $47: 433-435$ (1983).

23) Gaudette L.E. and Brodie B.B.; Relationship between the lipid solubility of drugs and their oxidation by liver microsomes. Biochemical Pharmacology, 2 : 89-96 (1959).

24) Workman P. and Brown J.M.; Structure-pharmacokinetic relationships for misonidazole analogues in mice. Cancer Chemother. Pharmacol., $6: 39-49(1981)$.

25) Rolinson G.N. and Batchelor F.R. ; Penicillin metabolites, Antimicrobial Agents and Chemotherapy, pp.654-660 (1962).

26) Toon S. and Rowland M.; Quantitative structure pharmacokinetic activity relationships with some tetracyclines. J. Pharm. Pharmacol., $31: 43$ p. (1979).

27) Dryer D.E. ; Clinical consequences of the lipophylicity and plasma protein binding of antiarrhythmic drugs and active metabolites in man. Ann. N.Y. Acad. Sci., 432 : $45-56$ (1984). 
28) Robinson D.C. ; Principles of pharmacokinetics. Topics in clinical pharmacology and therapeutics (edited by R.F. Maronde, Springer-Verlag, New York,USA.) 1-12 (1986).

29) Hirai K., Aoyama H., Irikura T., Iyobe S. and Mitsuhashi S. ; Differences in susceptibility to quinolones of outer membrane mutants of Salmonella typhimurium and Escherichia coli. Antimicrbial Agents and Chemotherapy., 29 : 535-538 (1986).

30) Dax E.M. and Partilla J.S. ; Adrenergic ligand liposolubility in membranes ; Direct assessment in a beta-adrenergic binding system. Molecular Pharmacology, $22: 5-7$ (1982).

31) Schafer G. ; Guanidines and biguanides. Pharmac. Ther., 8 : 275-295 (1979).

32) Alam A.S., Imondi A.R., Udinsky J. and Hagerman L.M. ; Bioavailability of ${ }^{14} \mathrm{C}$-sulpiride in dogs. Arch. int. Pharmacodyn., $242: 4-13$ (1979).

33) Workman P. and Brown J.M.; Structure-pharmacokinetic relationships for misonidazold analogues in mice. Cancer Chemother. Pharmacol., 6:39-49(1981).

34) Sherrer R.A. and Howard S.M. : Use of distribution coefficients in quantitative structure-activity relationships. J. Medicinal Chemistry, $20: 53-58$ (1977).

35) Eberlein Von W., Schmidt G., Reuter A. and Kutter E. ; Das ulkustherapeutikum pirenzepin (L-S 519) Arzneim.-Forsch., 27 : 356-359 (1977).

36) Clarke F.H. ; Ionization constants by curve fitting : Application to the determination of partition coefficients. J. Pharmaceutical Sciences., $73: 226-230$ (1984).

37) Lullmann $\mathrm{H}$. and Wehling M. ; The binding of drugs to different polar lipids in vitro. Biochemical Pharmacology, 28 : 3409-3415 (1979).

38) Cross P.E., Gadsby B., Holland G.F. and MacLamore W.M. ; Cerebrovasodilatation through selective inhibition of the enzyme carbonic anhydrase. 1. Substituted benzenedisulfonamides. J. of Medicinal Chemistry., 21 : 845-850 (1978).

39) Sallmann A.R. ; The history of diclofenac. The American J. of Medicine, 80 (supple 4 B) : 29-33 (1986).

40) Brimblecombe R.W., Duncan W.A.M., Durant G.J., Emmett J.C., Ganellin C.R. and Parsons M.E. ; Cimetidine-A non-thiourea $\mathrm{H}_{2}$-receptor antagonist. J. Int. Med. Res., 3 : 86-92 (1975).

41) Julkunen R.J.K. ; The absorption of warfarin from the rat small intestine in situ. J. Pharm. Pharmacol., 28 : 483-497 (1975).

42) Ashby J., Piddock L.J.V. and Wise R. ; An investigation of thd hydrophobicity of the quinolones. $J$. of Antimicrbial Chemotherapy., 16:805-808 (1985).

43) Nakajima T., Sunagawa M. and Hirohashi T. ; Studies of cyclodextrin inclusion complexes. II. Application of the partition coefficient method. Chem. Pharm. Bull., 32 : 401-408 (1984).

44) Brown R.M., Wise R., Andrews J.M. and Hancox J. ; Comparative pharmacokinetics and tissue penetration of sulbactam and ampicillin after concurrent intravenous aminisłration. Antimicrobial Agents and Chemotherapy, $21: 565-567$ (1982).

45) Wise R., Lockley R.M., Webberly M. and Dent J. ; Pharmacokinetics of intravenously administered ciprofloxacin. Antimicrobial Agents and Chemotherapy, $26: 208-210$ (1984).

46) Sisca T.S., Heel R.C. and Romankiewicz J.A. ; Cinoxacin : A review of its pharmacological properties and therapeutic efficacy in the treatment of urinary tract infections. Drugs, $25: 544-569$ (1983).

47) Hengstmann J.H. and Goronzy J. ; Pharmacokinetics of ${ }^{3} \mathrm{H}$-phenylephrine in man. Eur. J. Pharmacol., 21 : 335-341 (1982).

48) Klinge E., Mannisto P.T., Mantyla R., Mattila J. and Hanninen U. ; Single-and multiple-dose pharmacokinetics of pipemidic acid in normal volunteers. Antimicrobial Agents and Chemotherapy, $26: 69-73$ (1984).

49) Sirtori C.R., Franceschini G., Galli-Kienle M., Cighetti G., Galli G., Bondioli A. and Conti F. ; Disposition of metformin (N,N-dimethylbiguanide) in man. Clin. Pharmacol. Ther., 24 : 683-693 (1978). 
50) Wiesel F.A., Alfredsson G., Fhrnebo M. and Sedvall G. ; The pharmacokinetics of intravenous and oral sulpiride in healthy human subjects. Eur. J. Clin. Pharmacol., $17: 385-391$ (1980).

51) Strong J. and Johnson R. ; Pharmacology and toxicology of desmethylmisonidazole (DMM)-An hypoxic cell sensitizer. Proc. Am. Soc. Clin. Oncol., 1, 18 Meet. 30 (1982).

52) Carmine A.A. and Brogden R.N. ; Pirenzepine : A review of its pharmacodynamic and pharmacokinetic properties and therapeutic efficacy in peptic ulcer disease and other allied diseases. Drugs, $30: 85-126$ (1985).

53) Aoki F.Y., Sitar D.S. and Ogilvie R.I. ; Amantadine kinetics in healthy young subjects after long-term dosing. Clin. Pharmacol. Ther., 26 : 729-736 (1979).

54) Gundert Remy U., Schmidlin O. and Hinderling P.H. ; Pharmacokinetics and pharmacodynamics of atropine in healthy humans. Arch. Pharmacol., 311, Suppl. R 75 (1980).

55) Strong J.M., Schwade J., Poplack D.G. and Miller E. ; Pharmacokinetic studies of parenteral misonidazole in monkeys and man. Proc. Am. Assoc. Cancer Res. 20, 70 Meet., 200 (1979).

56) Robinson D.C. ; Topics in clinical pharmacology and therapeutics (edited by R.F. Malonde, Springer Verlag, New York, USA.) pp. 1-10 (1986).

57) Brunk S.F. and Delle M. ; Morphine metabolism in man. Clin. Pharmacol. Ther., $16: 51-57$ (1974).

58) Brogden R.N., Heel R.C., Speight T.M. and Avery G.S. ; Piroxicam : A review of its pharmacological properties and therapeutic efficacy. Drugs, $22: 165-187$ (1981).

59) Danan G., Montay G., Cunci R. and Erlinger S. ; Pefloxacin kinetics in cirrhosis. Clin. Pharmacol. Ther., $38:$ 439-442 (1985).

60) Norlander B., Bodemar G. and Walan A.; Therapeutic blood concentrations and renal excretion of cimetidine. Scand. J. Gastroenterol., $15: 75$ (1980).

61) Nelson E., Powell J.R., Conrad K., Likes K., Byers J., Baker S. and Perrier D.; Phenobarbital pharmacokinetics and bioavailability in adults. J. Clin. Pharmacol, 22 : 141-148 (1982).

62) Shull, Jr. H.J., Wilkinson G.R., Johnson R. and Schenker S. ; Normal disposition of oxazepam in acute viral hepatitis and chirrhosis. Annals of Internal Medicine, $84: 420-425$ (1976).

63) McClain D.A. and Hug C.C. ; Intravenous fentanyl kinetics. Clin. Pharmacol. and Ther., $28: 106-114$ (1980).

64) Eckard R. and Weyhenmeyer R.; Pharmacokinetics of bencyclane after single dose administration to hdalthy volunteers. Arzneim. Forsch., 35 (II) : 1587-1590 (1985). 